\title{
VALIDITAS BAHAN AJAR GERAK MELINGKAR BERBASIS AUTHENTIC LEARNING DI LINGKUNGAN LAHAN BASAH UNTUK MELATIH KETERAMPILAN PEMECAHAN MASALAH
}

\author{
Muhammad Hafiz Ridho', Mustika Wati' ${ }^{1}$ Misbah', dan Saiyidah Mahtari' \\ ${ }_{1}^{1}$ Pendidikan Fisika, FKIP, Universitas Lambung Mangkurat Jl Brigjen H. Hasan Basry, \\ Banjarmasin, 70124, Indonesia \\ E-mail: mustikapfis@ulm.ac.id
}

\begin{abstract}
ABSTRAK
Tujuan penelitian ini ialah mendeskripsikan validitas bahan ajar gerak melingkar berbasis authentic learning di lingkungan lahan basah untuk melatih keterampilan pemecahan masalah peserta didik. Penelitian ini merupakan penelitian dan pengembangan menggunakan model ASSURE. Instrumen yang digunakan dalam penelitian ini berupa lembar validasi bahan ajar. Berdasarkan hasil validasi diperoleh bahwa bahan ajar gerak melingkar memiliki kategori valid dengan skor validasi sebesar 3,40. Diperoleh simpulan bahwa bahan ajar gerak melingkar berbasis authentic learning di lingkungan lahan basah untuk melatih keterampilan pemecahan masalah dinyatakan valid. Selanjutnya bahan ajar dapat digunakan dalam proses pembelajaran di kelas untuk mengetahui kepraktisan dan efektivitas bahan ajar yang dikembangkan.
\end{abstract}

Kata kunci: validitas, gerak melingkar, authentic learning, lahan basah, keterampilan pemecahan masalah

\begin{abstract}
The purpose of this study is to describe the validity of teaching materials in circular motion based on authentic learning in the wetland environment to train students' problem-solving skills. This research is research and development using the ASSURE model. The instrument used in this study was in the form of teaching material validation sheets. Based on the analysis of the data obtained that the teaching material in circular motion has a valid category. It was concluded that teaching materials in circular motion based on authentic learning in the wetland environment at to practice problem-solving skills declared valid, and can be used in the learning process in class. Furthermore, teaching materials can be used in the learning process in the classroom to find out the practicality and effectiveness of teaching materials developed.
\end{abstract}

Keywords: validity, circular motion, authentic learning, wetland, problem-solving skills

DOI: http://dx.doi.org/10.15575/jotalp.v5i2.8453

Received: 05 Mei 2020 ; Accepted: 09 Juli 2020 ; Published: 31 Agustus 2020 


\section{PENDAHULUAN}

Fisika merupakan salah satu cabang ilmu sains yang mempelajari berbagai macam fenomena atau gejala fisis yang terjadi di alam (Triuitami \& Ruwanto, 2017). Pembelajaran fisika bertujuan untuk mengembangkan kemampuan berpikir peserta didik dalam memecahkan masalah (Amrita, Jamal, \& Misbah, 2016; Astra \& Jannah, 2012; Habibi, Zainuddin, \& Misbah, 2017; Yuberti, Anugrah, Saregar, Misbah, \& Jermsittiparsert, 2019), dengan cara menerapkan pengetahuan dan pemahaman mereka pada situasi sehari-hari (Azizah, Yuliati, \& Latifah, 2015). Oleh karena itu, keterampilan pemecahan masalah sangat diperlukan untuk menghasilkan berbagai solusi inovatif dalam menghadapi permasalahan dunia saat ini maupun mendatang.

Peserta didik mempelajari fisika dalam rangka mengembangkan keterampilan memecahkan permasalahan yang berkaitan erat dengan fenomena alam dalam kehidupan bermasyarakat (Selamet, Sadia, \& Suma, 2013). Mata pelajaran fisika memiliki kaitan yang erat antara konsep dan lingkungan sekitar (Damayanti, 2013; Misbah, Hirani, Annur, Sulaeman, \& Ibrahim, 2020). Penyampaian materi dalam proses pembelajaran fisika yang dikaitkan dengan lingkungan sekitar akan lebih bermakna (Hasani, Hartini, \& Annur, 2019; Misbah \& Fuad, 2019). Bermakna memiliki arti bahwa peserta didik mampu menerapkan pembelajaran untuk menyelesaikan permasalahan dalam kehidupan (Widoyoko, 2017).

Kemampuan peserta didik sudah seharusnya sejalan dengan kualitas sarana/prasarana pembelajaran peserta didik, salah satunya adalah bahan ajar. Bahan ajar yang baik dapat mendukung kegiatan pembelajaran secara efektif dan efisien sehingga tujuan pembelajaran akan lebih mudah tercapai (Nurhadiyanto, 2015). Dengan adanya materi ajar yang baik, peserta didik juga dapat belajar dan mendiskusikan materi ajar tersebut sebelum pembelajaran di kelas dimulai, sehingga mereka lebih mudah mengetahui kompetensi apa yang akan mereka capai di pembelajaran tersebut (Satriawan \& Rosmiati, 2016).

Daerah Kalimantan Selatan sangat berkaitan erat lahan basah, memiliki karakteristik khas yang dapat dirancang sebagai objek masalah maupun sebagai sumber belajar untuk meningkatkan hasil belajar siswa (Iriani, Herlina, Irhasyuarna, \& Sanjaya, 2019; Yunita, Saadi, \& Kusasi, 2018). Belajar dengan mengaitkan materi pembelajaran dengan kehidupan nyata peserta didik akan membuat pembelajaran menjadi lebih dimaknai (Hartini, Firdausi, Misbah, \& Sulaeman, 2018; Hartini, Isnanda, Wati, Misbah, An'Nur, \& Mahtari, 2018). Oleh karena itu diperlukan sebuah pembelajaran fisika yang dapat mengaitkan antara materi fisika dengan fakta atau fenomena yang terjadi di sekitar tempat tinggal peserta didik.

Hasil wawancara dengan guru fisika di sekolah, diperoleh bahwa peserta didik masih kesulitan dalam proses analisis menyelesaikan soal-soal tingkat C4-C6. Proses analisis ini berhubungan dengan tingkat pemecahan masalah seperti memvisualisasikan fenomena dalam permasalahan yang diberikan, menentukan besaran yang diketahui dan yang ditanyakan, serta bagaimana menyelesaikan permasalahan tersebut menggunakan persamaan yang tepat. Hal ini sejalan dengan pendapat Markawi (2015) bahwa banyak peserta didik yang kurang memiliki kemampuan menyelesaikan soal-soal secara sistematis, sulit mencerna pokok pertanyaan, sulit menentukan besaran-besaran fisika dan simbol-simbol yang terdapat dalam pertanyaan, serta sulit menentukan konsep, prinsip, teori, hukum dan rumus yang dipakai untuk memecahkan suatu persoalan. Selain itu juga diperoleh informasi bahwa belum adanya bahan ajar fisika yang mengaitkan materi fisika dalam permasalah yang authentic pada kehidupan sehari-hari membuat proses pembelajaran menjadi kurang bermakna. Peserta didik menjadi kesulitan dalam memahami fisika, sehingga keterampilan 
pemecahan masalah peserta didik belum dilatihkan secara maksimal.

Salah satu solusi yang dapat digunakan untuk menyelesaikan permasalahan tersebut dengan mengembangkan bahan ajar yang mampu melatihkan peserta didik untuk menyelesaikan masalah. Bahan ajar fisika dan model pembelajaran yang mengantarkan peserta didik dari pengalaman sehari-hari ke materi fisika sangat diperlukan dalam pembelajaran fisika (Fayakun \& Joko, 2015). Inovasi yang bisa diterapkan dalam proses peningkatan kualitas pembelajaran ialah mengembangkan bahan ajar berbasis bermuatan authentic learning.

Authentic learning berfokus pada keadaan di dunia nyata, masalah-masalah yang kompleks beserta solusinya, kegiatan berbasis masalah, studi kasus, dan partisipasi dalam praktik individu maupun kelompok (Lombardi, 2007). Salah satu fokus authentic learning adalah kegiatan berbasis masalah yang tentunya jika diterapkan akan melatih keterampilan pemecahan masalah peserta didik. Pemecahan masalah adalah sebuah upaya untuk menemukan jalan keluar dari sebuah kesulitan agar tujuan yang diinginkan segera tercapai (Polya, 1973). Pada praktiknya, kegiatan berbasis masalah memerlukan tahapan-tahapan pemecahan masalah, salah satunya adalah tahap pemecahan oleh (Heller, Keith, \& Anderson, 1992). Heller mengemukakan 5 tahapan secara rinci dan runtut untuk memecahkan suatu masalah fisika yaitu visualisasi masalah, deskripsi masalah, merencanakan solusi, melaksanakan solusi, dan evaluasi solusi.

Peserta didik tentu kesulitan jika masalah yang disajikan tidak pernah ditemui oleh peserta didik sebelumnya, di sinilah peranan penting authentic learning yang diterapkan dalam materi ajar. Salah satu contoh dari authentic learning yang ada di lingkungan lahan basah ialah kesenian Sinoman Hadrah, yang merupakan salah satu adat dari masyarakat Banjar Kalimantan Selatan.
Kesenian ini terdiri dari lima atau enam orang pendendang syair sekaligus penabuh rebana, serta pemutar payung ubur-ubur ditambah penari rudat berjumlah 20 sampai dengai 30 orang. Sinoman Hadrah biasanya ditampilkan pada saat menyambut tamu kehormatan, acaraacara hari besar nasional, upacara-upacara peresmian suatu tempat, serta upacara perkawinan saat mempelai pria dibawa ke tempat kediaman mempelai wanita untuk disandingkan. Salah satu hal yang menjadi perhatian saat kesenian ini ditampilkan yaitu payung besar yang dihias indah untuk memayungi pejabat yang disambut atau pengantin pria yang akan disandingkan. Payung ini dimainkan dengan cara diputar-putar di atas kepala orang yang diiringi, sambil pemain lain melantunkan syair-syair pujian kepada Rasulullah (Khair, 2003). Payung yang diputar dengan kecepatan sudut tertentu oleh pemain Sinoman Hadrah tersebut merupakan salah satu bentuk fenomena yang bisa dijadikan sumber belajar fisika materi gerak melingkar. Adanya kaitan antara materi gerak melingkar dengan kesenian Sinoman Hadrah yang sangat dekat dengan dunia nyata masyarakat Kalimantan Selatan merupakan bentuk authentic learning di lingkungan lahan basah.

Peneliti meyakini dengan mengembangkan bahan ajar berbasis authentic learning akan menggugah minat peserta didik serta mempermudah peserta didik untuk memahami dan memecahkan permasalahan yang disajikan pada materi ajar. Pengembangan bahan ajar berbasis authentic learning juga didukung secara empiris oleh penelitian Sutiniasih (2018) dan Rahmah (2018) yang menyatakan bahwa penggunaan modul fisika bermuatan authentic learning layak untuk digunakan dalam melatihkan kemampuan pemecah masalah peserta didik. Penggunaan authentic learning dapat melatih pemahaman konsep, motivasi belajar, kemampuan berpikir kritis peserta didik, dan hasil belajar (Griyanika, 2014; Sulistiani, 2018; Triuitami \& Ruwanto, 2017). Dari penelitian yang sudah ada, belum ada yang 
mengaitkan authentic learning dengan kesenian/budaya daerahnya. Oleh karena itu, keterampilan pemecahan masalah peserta didik dapat dilatihkan dengan mengembangkan bahan ajar gerak melingkar berbasis authentic learning sebagai solusi. Dalam penelitian ini, peniliti menambahkan kesenian budaya banjar yaitu Sinoman Hadrah yang dikaitkan dengan materi fisika gerak melingkar.

Bahan ajar harus dinilai kelayakannya agar bisa mendapatkan bahan ajar yang baik. Salah satu aspek kelayakan bahan ajar yaitu validitas. Penelitian ini bertujuan untuk mendeskripsikan validitas bahan ajar gerak melingkar berbasis athentic learning untuk melatih keterampilan pemecahan masalah.

\section{METODE PENELITIAN}

Jenis penelitian yang dilakukan yaitu penelitian dan pengembangan, menggunakan model ASSURE. Namun dalam penelitian ini hanya meliputi tahap Analyse learner, State objective, Selection of Media and Materials and Utilization of instructional materials. Tahapan pengembangan yang digunakan, dapat dilihat pada Gambar 1.

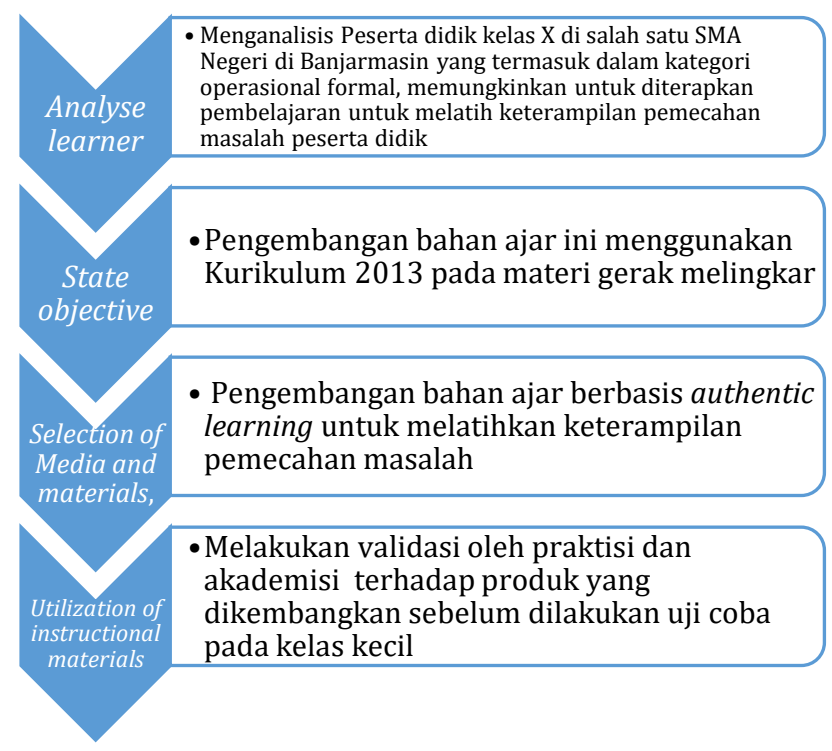

Gambar 1. Tahapan Pengembangan
Produk yang dihasilkan berupa bahan ajar gerak melingkar berbasis athentic learning untuk melatih keterampilan pemecahan masalah peserta didik. Kelayakan produk ini dinilai dari validitas. Validitas berasal dari kata validity artinya sejauh mana ketepatan dan kecermatan instrumen pengukur dalam melakukan fungsinya (Matondang, 2009). Validitas adalah kesesuaian pengukuran dengan apa yang diukur. Pengembangan bahan ajar dalam penelitian ini menggunakan validitas konstruk. Menguji validitas dapat digunakan pendapat para ahli (Akbar, 2016). Validasi bahan ajar ditinjau dari aspek format, bahasa, isi, penyajian bahan ajar, dan manfaat/kegunaan bahan ajar. Valid dan tidaknya suatu perangkat pembelajaran ditentukan dengan cara membandingkan kriteria validitas perangkat pembelajaran dan hasil skor penilaian yang diperoleh (Widoyoko, 2017). Kriteria validitas bahan ajar yang digunakan dapat dilihat pada Tabel 1 berikut.

Tabel 1. Kriteria Validitas Bahan Ajar

\begin{tabular}{ccc}
\hline No & Rata-Rata Skor & Kategori \\
\hline 1 & $\bar{x}>3,4$ & Sangat Valid \\
\hline 2 & $2,8<\bar{x} \leq 3,4$ & Valid \\
\hline 3 & $2,2<\bar{x} \leq 2,8$ & Cukup Valid \\
\hline 4 & $1,6<\bar{x} \leq 2,2$ & Kurang Valid \\
\hline 5 & $\bar{x} \leq 1,6$ & Sangat Kurang Valid \\
\hline & & (Widoyoko, 2017)
\end{tabular}

\section{HASIL DAN PEMBAHASAN}

Validasi merupakan kegiatan memperoleh persetujuan maupun pengesahan mengenai sebuah perangkat berdasarkan kesesuaian dengan kriteria yang dibutuhkan. Bahan ajar yang dikembangkan nantinya akan digunakan peserta didik dalam setiap pertemuan sebagai referensi dan sumber belajar peserta didik. Pengembangan bahan ajar berbasis authentic learning dirancang dengan tujuan untuk melatihkan keterampilan pemecahan masalah peserta didik dengan disesuaikan pada 
kurikulum 2013 dan kebutuhan di sekolah. Peneliti mengembangkan materi ajar dengan materi gerak melingkar yang terdiri dari sampul depan, kata pengantar, peta konsep, tujuan pembelajaran, pojok mengingat, uraian materi, contoh soal, latihan terbimbing, uji kompetensi, ilmuwan kita, rangkuman, dan daftar pustaka. Sumber-sumber tersebut disusun dan dicantumkan dalam daftar pustaka pada materi ajar peserta didik pada setiap pertemuannya. Berdasarkan konsep yang akan digunakan, peneliti menganalisis contoh authentic learning yang akan dimuat ke dalam materi ajar yang ditunjukkan Tabel 2.

Tabel 2. Authentic Learning pada materi gerak melingkar

\begin{tabular}{|c|c|}
\hline Fenomena & Konsep Fisika \\
\hline $\begin{array}{l}\text { Gerak } \\
\text { payung } \\
\text { hadrah. }\end{array}$ & $\begin{array}{l}\text { Gerak melingkar merupakan } \\
\text { gerak yang lintasannya } \\
\text { berbentuk lingkaran, salah } \\
\text { satu contohnya adalah gerak } \\
\text { perputaran payung sinoman } \\
\text { hadrah }\end{array}$ \\
\hline $\begin{array}{lr}\text { Payung } & \text { sinoman } \\
\text { hadrah } & \text { berputar } \\
\text { secara berulang-ulang. }\end{array}$ & $\begin{array}{lr}\text { Pergerakan } & \text { berulang } \\
\text { memunculkan } & \text { besaran } \\
\text { periode (waktu untuk satu } \\
\text { kali putaran) dan frekuensi } \\
\text { (putaran dalam satuan } \\
\text { waktu) yang keduanya } \\
\text { memiliki hubungan. }\end{array}$ \\
\hline $\begin{array}{l}\text { Manik-manik } r \text { pada } \\
\text { payung sinoman } \\
\text { hadrah berpindah } \\
\text { ketika payung diputar. }\end{array}$ & $\begin{array}{l}\text { Pergerakan manik-manik } \\
\text { memunculkan besaran yakni } \\
\text { perpindahan sudut. }\end{array}$ \\
\hline $\begin{array}{lr}\text { Payung } & \text { sinoman } \\
\text { hadrah diputar dengan } \\
\text { kecepatan } \\
\text { tertentu. }\end{array}$ & $\begin{array}{l}\text { Perputaran payung sinoman } \\
\text { hadrah memiliki kecepatan } \\
\text { sudut. }\end{array}$ \\
\hline $\begin{array}{lr}\text { Payung } & \text { sinoman } \\
\text { hadrah yang diputar } & \text { memunculkan besaran } \\
\text { kecepatan rudut, } & \text { sudut } \\
\text { kecepatan } & \text { linier, } \\
\text { periode, rerta } & \text { srekuensi, yang semua } \\
\text { besaran tersebut } \\
\text { memiliki keterkaitan } \\
\text { besaran linier dan } \\
\text { besaran sudut. }\end{array}$ & $\begin{array}{l}\text { Pengulangan perputaran } \\
\text { payung sinoman hadrah } \\
\text { memunculkan besaran fisika } \\
\text { yakni frekuensi, } \\
\text { banyaknya putaran setiap } \\
\text { satuan waktu. }\end{array}$ \\
\hline $\begin{array}{lr}\text { Untuk } & \text { memutar } \\
\text { payung } & \text { sinoman }\end{array}$ & $\begin{array}{l}\text { Lingkaran payung dan kayu } \\
\text { terletak dalam titik atau }\end{array}$ \\
\hline
\end{tabular}

\begin{tabular}{|c|c|}
\hline & \\
\hline $\begin{array}{lr}\text { hadrah, } & \text { pemain } \\
\text { menggunakan } & \text { kayu } \\
\text { yang } & \text { terhubung } \\
\text { dengan } & \text { lingkaran } \\
\text { payung. } & \\
\end{array}$ & $\begin{array}{l}\text { sumbu pusat yang sama, } \\
\text { sehingga nilai kecepatan } \\
\text { sudut antara batang pemutar } \\
\text { (kayu) dengan lingkaran } \\
\text { payung bernilai sama. }\end{array}$ \\
\hline $\begin{array}{lr}\text { Memutar gir } & \text { depan } \\
\text { sepeda } & \text { yang } \\
\text { dihubungkan rantai } \\
\text { dengan gir belakang } \\
\text { sepeda. }\end{array}$ & $\begin{array}{l}\text { Gir depan dan gir belakang } \\
\text { sepeda dihubungkan } \\
\text { menggunakan rantai sepeda, } \\
\text { jika gir depan berputar } \\
\text { makan gir belakang juga } \\
\text { berputar. Nilai kecepatan } \\
\text { linier kedua gir tersebur } \\
\text { sama. }\end{array}$ \\
\hline $\begin{array}{lr}\text { Mesin jam tangan } \\
\text { analog } & \text { yang } \\
\text { menggunakan roda- } \\
\text { roda bergerigi yang } \\
\text { saling bersinggungan. }\end{array}$ & $\begin{array}{l}\text { Jika ada dua roda gerigi yang } \\
\text { bersinggungan maka kedua } \\
\text { roda tersebut akan berputar } \\
\text { saling berlawanan arah } \\
\text { dengan kecepatan linier yang } \\
\text { bernilai sama. }\end{array}$ \\
\hline
\end{tabular}

Berikut cover bahan ajar gerak melingkar berbasis authentic learning dapat dilihat pada Gambar 2 berikut.

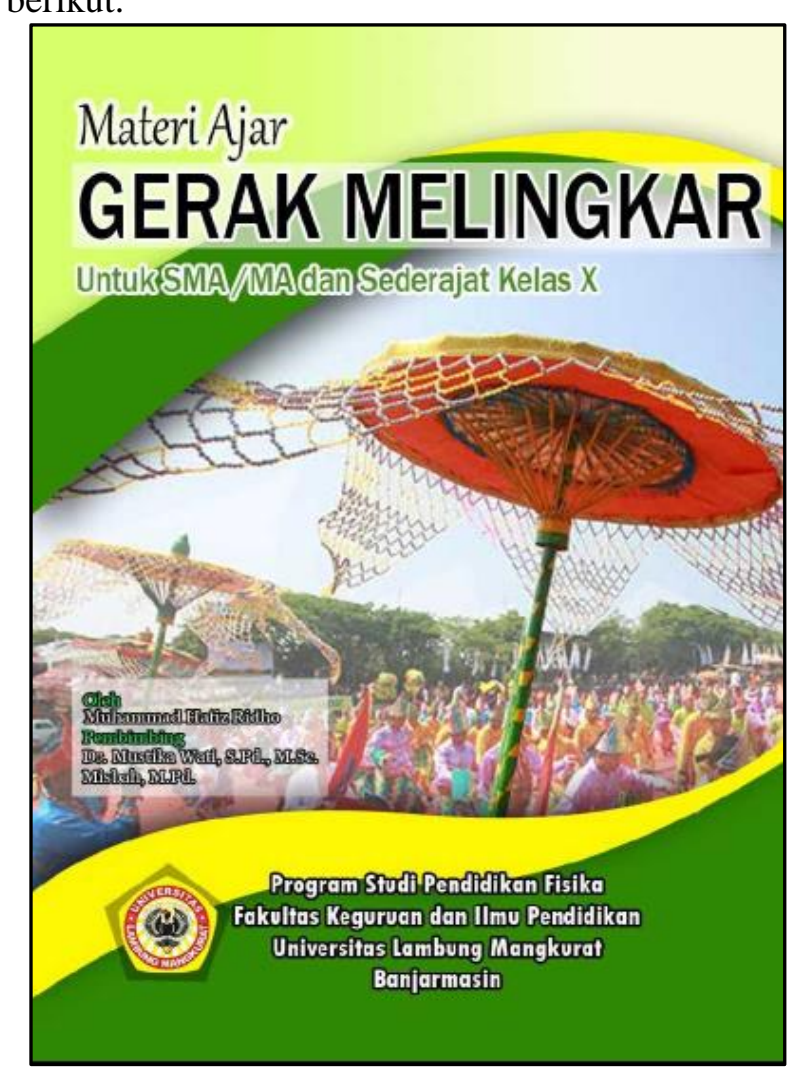

Gambar 2. Cover bahan ajar gerak melingkar berbasisauthentic learning 
Setiap awal pertemuan disajikan gambar authentic dan pertanyaan authentic yang memotivasi peserta didik agar terlibat aktif dalam pembelajaran. Indikator pembelajaran juga disediakan agar peserta didik mengetahui batasan materi dan lebih terarah dalam proses pembelajaran. Setelah menyajikan indikator pembelajaran, materi ajar yang dikembangkan memuat uraian materi yang berisi berbagai macam informasi authentic tentang gerak melingkar, ditinjau dari contoh fenomena dan gambar yang berhubungan dengan lingkungan daerah peserta didik yaitu Kalimantan Selatan. Salah satu contoh authentic learning ialah Sinom Hadrah. Berikut tampilan salah satu contoh authentic learning yang digunakan dapat dilihat pada Gambar 3.

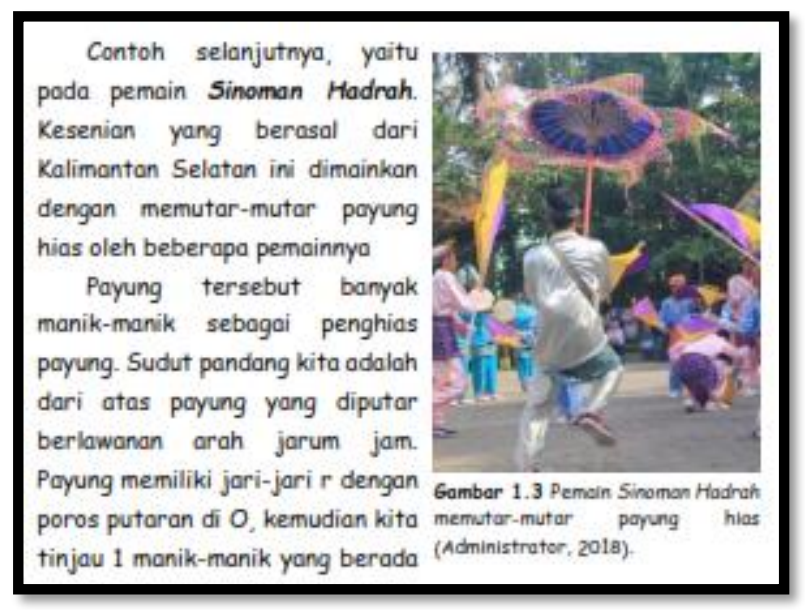

Gambar 3. Salah satu authentic learning kesenian Sinoman Hadrah

Setiap akhir subbab terdapat contoh soal authentic sebagai bekal awal melatihkan tahap pemecahan masalah peserta didik. Kemudian terdapat latihan terbimbing yang penyelesaiannya harus dipecahkan oleh peserta didik melalui diskusi kelompok. Ada pula rangkuman yang berisi inti sari dari uraian materi untuk membantu peserta didik menemukan ide pokok pembelajaran. Setelah itu materi ajar menyajikan latihan lanjutan yang penyelesaiannya harus dipecahkan peserta didik secara individu. Pemberian soal-soal secara bertahap diharapkan dapat membuat peserta didik lebih mudah dalam memahami suatu permasalahan. Berikut contoh soal yang disajikan dapat dilihat pada Gambar 4,

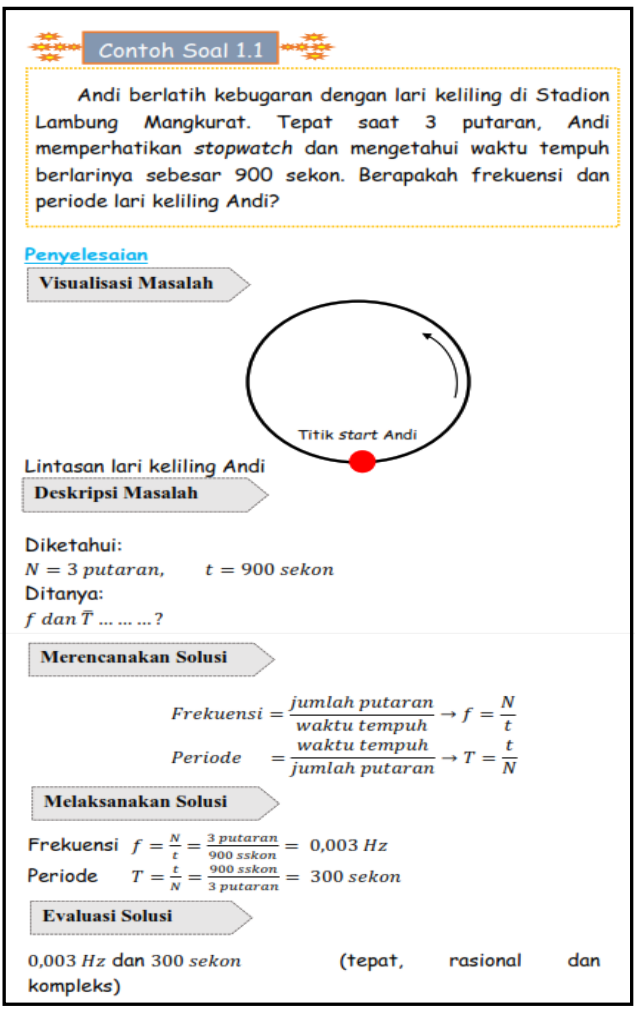

Gambar 4. Contoh soal yang terdapat dalam bahan ajar

Uji kompetensi juga disediakan pada materi ajar yang dikembangkan agar peserta didik dapat mengetahui sampai mana tingkat pemahaman peserta didik mengenai pembelajaran yang telah dipelajari. Bagian akhir materi ajar memuat daftar pustaka sebagai informasi sumber rujukan yang digunakan peneliti dalam mengembangkan materi ajar gerak melingkar ini. Ada pula kunci jawaban uji kompetensi sehingga peserta didik dapat belajar mandiri karena dapat memeriksa sendiri hasil jawaban dari setiap soal uji kompetensi yang peserta didik kerjakan.

Penyelesaian untuk contoh soal, soal latihan terbimbing, dan soal latihan lanjutan menggunakan tahapan pemecahan masalah 
Heller. Indikator pemecahan masalah Heller yaitu visualisasi masalah, deskripsi masalah, merencanakan solusi, melaksanakan solusi, dan evaluasi. Pertama-tama peserta didik akan dituntut untuk mampu melakukan visualisasi masalah, tahap ini peserta didik akan menggambarkan situasi fisis permasalahan fisika yang disajikan. Kemudian peserta didik harus mendeskripsikan masalah, yaitu menuliskan besaran yang diketahui dan ditanyakan. Kemudian peserta didik merencanakan solusi, di tahap ini peserta didik menuliskan konsep, prinsip, persamaan maupun tahapan matematis secara runtut untuk memecahkan masalah. Selanjutnya peserta didik melaksanakan solusi yang sudah direncanakan dengan mensubtitusikan nilai-nilai besaran fisika terkait ke dalam tahapan matematis. Terakhir peserta didik melakukan evaluasi solusi mengenai tahap pemecahan masalah yang sudah peserta didik lakukan.

Berikut ini data hasil validasi bahan ajar oleh para ahli disajikan pada Tabel 3.

Tabel 3. Hasil Validasi Bahan Ajar

\begin{tabular}{clcc}
\hline No. & Aspek Penilaian & $\begin{array}{c}\text { Rata-rata } \\
\text { skor }\end{array}$ & Kategori \\
\hline 1 & Format bahan ajar & 3,29 & Valid \\
\hline 2 & Bahasa bahan ajar & 3,34 & Valid \\
\hline 3 & Isi bahan ajar & 3,40 & Valid \\
\hline 4 & $\begin{array}{l}\text { Penyajian bahan } \\
\text { ajar }\end{array}$ & 3,46 & $\begin{array}{c}\text { Sangat } \\
\text { valid }\end{array}$ \\
\hline 5 & $\begin{array}{l}\text { Manfaat/ kegunaan } \\
\text { bahan ajar }\end{array}$ & 3,50 & $\begin{array}{c}\text { Sangat } \\
\text { valid }\end{array}$ \\
& & Valid \\
\hline \multicolumn{2}{l}{ Validitas bahan ajar } & 3,40 & Tinggi \\
\hline Reliabilitas bahan ajar & 0,98 & \\
\hline
\end{tabular}

Tabel 3 di atas menunjukkan bahwa hasil rerata aspek validasi bahan ajar untuk materi gerak melingkar memperoleh skor 3,40 dengan kategori valid. Selain itu, reliabilitas bahan ajar memperoleh skor 0,98 dengan kategori sangat tinggi, sehingga bahan ajar berbasis authentic learning yang dikembangkan baik dan layak digunakan dalam penelitian guna melatihkan keterampilan pemecahan masalah peserta didik. Pengembangan bahan ajar merupakan salah satu kompetensi yang wajib dimiliki oleh seorang pendidik. Hal ini penting dilakukan agar pembelajaran menjadi efisien, efektif, serta tidak melenceng dari tujuan yang ingin dicapai (Santyadiputra \& Pradnyana, 2017). Selain itu, perkembangan zaman yang saat ini membawa pada abad 21 menuntut pendidik mampu mewujudkan pemenuhan keterampilan bagi peserta didik dalam menyambut berbagai bentuk tantangan kehidupan global. Luaran dari hasil pembelajaran yang diharapkan nantinya bukan hanya berorientasi pada pemahaman materi/konsep, tapi bagaimana pembelajaran tersebut mampu memberikan pengalaman dan bekal bagi peserta didik untuk menghadapi kehidupan nyata di lingkungan mereka. Pengembangan bahan ajar yang berbasis authentic learning ini diharapkan mampu menjadi perangkat pendukung untuk melatihkan keterampilan pemecahan masalah peserta didik.

Suatu bahan ajar dapat dinyatakan valid apabila seluruh komponennya telah memenuhi kriteria minimum valid. Validasi bahan ajar merupakan suatu proses yang dilakukan untuk menguji kesesuaian antara bahan ajar dengan kompetensi yang dijadikan sebagai target belajar. Data hasil validasi materi ajar gerak melingkar pada Tabel 3 menunjukkan hasil validitas pada seluruh aspek berkategori valid dan reliabilitas sangat tinggi. Bahan ajar dinyatakan valid oleh validator karena susunan materi ajar pembelajaran yang dikembangkan telah memenuhi syarat-syarat penyusunan materi ajar pembelajaran yang baik. Adapun aspek yang diamati diantaranya ialah aspek format, bahasa, isi, penyajian, dan manfaat kegunaan bahan ajar. 
Secara lebih rinci, aspek format terdiri atas dua belas (12) kriteria yang mengukur daya tarik sampul, rumusan tujuan pembelajaran, komponen materi ajar yang terpenuhi, sistem penomoran, jenis dan ukuran huruf, desain dan kesesuaian tata letak, teks dan ilustrasi gambar, ilustrasi gambar yang otentik, kesesuaian format kolom dengan format kertas, kesesuaian ringkasan materi dengan materi, kesesuaian ukuran fisik buku dengan peserta didik serta kualitas cetak. Seluruh aspek tersebut harus memenuhi kriteria minimum dan tersusun secara sistematis, karena susunan yang runtut dan sitematis dapat memudahkan peserta didik memahami materi secara keseluruhan (Prasetiyo \& Perwiraningtyas, 2017). Hasil validasi untuk bahan ajar gerak melingkar memperoleh skor dengan kategori valid untuk seluruh bahan ajar. Hasil yang diperoleh menunjukkan bahwa format materi ajar yang dikembangkan telah berkriteria baik dan sesuai untuk digunakan dalam melatihkan keterampilan pemecahan masalah. Hal ini sejalan dengan Prastowo (2014) yang menyatakan bahwa format materi ajar yang baik harus memenuhi beberapa karakteristik seperti desain yang jelas dan menarik, urutan isi yang runtut, judul yang singkat, struktur kognitif jelas, komponen materi ajar lengkap, mudah dibaca, serta ukuran teks yang terstruktur. Daya dukung format yang baik mampu meningkatkan ketertarikan peserta didik kepada materi ajar yang dikembangkan, sehingga perhatian mereka pada proses pembelajaran akan lebih terkendali. Sesuai dengan Sari (2017) yang menyatakan bahwa kesesuaian isi pada materi ajar pembelajaran, kejelasan petunjuk, kejelasan format, penyusunan materi dan kesesuaian antara materi pembelajaran mampu membantu peserta didik lebih mudah dalam memahami materi.

Selain aspek format, bahasa menjadi salah satu aspek penting yang juga menunjang kevalidan dari materi ajar yang dikembangkan. Bahasa yang komunikatif dan sesuai dengan kaidah mampu memberikan kemudahan pada pembaca untuk memahami isi dari bacaan tersebut. Aspek Bahasa memperoleh skor dengan kategori valid, yang mana seluruh aspek penyusunnya memenuhi kriteria baik. Materi ajar yang dikembangkan telah disesuaikan dengan tingkat perkembangan peserta didik baik ditinjau dari kematangan berpikir, maupun emosi social mereka. Perkembangan intelektual sangatlah substansial, karena sifat egosentrik, anak menjadi lebih bersifat logis (Novikasari, 2009). Menyusun materi ajar sesuai dengan tingkat perkembangan peserta didik akan menunjang pola berpikir mereka yang pada awalnya masih berpikir secara abstrak menuju berpikir secara kritis, hal ini merupakan salah satu treatment yang tepat digunakan dalam melatihkan keterampilan pemecahan masalah. Selain itu, gaya Bahasa yang dialogis dan juga interaktif menciptakan suasana membaca menjadi lebih bermakna. Peserta didik bukan hanya melakukan kegiatan membaca, namun mereka juga mampu merespon isi bacaan secara mendiri dengan bimbingan dari guru.

Adapun isi materi ajar peserta didik memiliki tiga kriteria yaitu cakupan materi, akurasi materi, dan kemutakhiran. Rerata skor untuk aspek isi materi memperoleh kategori valid, dimana hal ini mengindikasikan bahwa isi materi telah memenuhi seluruh komponen yang dipersyaratkan. Kriteria cakupan materi terdiri dari keluasan serta kedalaman materi yang berisi seberapa lengkap materi yang disajikan. Segi 
akurasi materi dalam materi ajar juga sudah baik, yang mencakup akurasi fakta, konsep, peta konsep, prinsip hukum, teori, istilah, simbol, dan satuan. Kemutakhiran isi materi di dukung dengan berbagai sumber baik cetak maupun elektronik sehingga berisi materi termutakhir sesuai dengan kebutuhan pembelajaran terkini.

Aspek selanjutnya yang menjadi penilaian ialah aspek penyajian yang memperoleh skor dengan kategori valid. Aspek penyajian terbagi menjadi tiga kriteria, yang pertama ialah teknik penyajian. Aspek ini mencakup konsistensi sistematika sajian dalam bab/subbab, kelogisan penyajian, keruntutan konsep, hubungan antara fakta, antar konsep, dan antar prinsip, serta antar teori, keseimbangan antara bab dan keseimbangan substansi antara subbab dalam bab, kesesuaian/ketepatan ilustrasi dengan materi dalam bab, penyajian tabel, gambar, dan lampiran yang disertai dengan rujukan terkini, dan identitas tabel, gambar dan lampiran. Bahan ajar yang dikembangkan telah dirancang khusus berdasarkan hasil studi literatur pada berbagai rujukan terkini sehingga penyajiannya memperhatikan keterkaitan satu aspek dengan lainnya, komposisi penyusunan terlihat kompak dan berisi. Penggunaan materi ajar yang baik mampu menuntun peserta didik dalam memecahkan masalah melalui konsep, matematis dan prinsip fisika akan membuat peserta didik lebih aktif serta menuntut peserta didik untuk lebih mengaplikasikan pengetahuannya (Maulida \& Simanjuntak, 2015). Aspek kedua ialah pendukung penyajian materi yang meliputi kata pengantar, materi pembelajaran yang berkaitan dengan authentic learning, contoh soal, latihan terbimbing, latihan lanjutan melatihkan keterampilan pemecahan masalah, rangkuman, uji kompetensi, lampiran daftar pustaka, dan lampiran kunci jawaban.
Aspek pendukung menjadi salah satu ciri khas dan pembeda dengan materi ajar pada umumnya, karena disusun sesuai dengan kebutuhan pendidik yang dalam penelitian ini disusun untuk melatihkan keterampilan pemecahan masalah.

Terakhir ialah kriteria penyajian pembelajaran yang terdiri atas fleksibel untuk digunakan dengan model pengajaran langsung maupun kooperatif, berpusat pada peserta didik dan guru, melibatkan peserta didik, keterjalinan komunikasi interaktif, sesuai dengan karakteristik materi pembelajaran, mampu merangsang kedalaman berpikir peserta didik, mampu memunculkan umpan balik untuk evaluasi diri, menumbuhkan rasa ingin tahu, dan memberikan tantangan untuk belajar lebih jauh. Guru atau tenaga pendidik perlu memahami karakteristik isi pesan pembelajaran yang akan disampaikan sehingga penyajian tidak berteletele, sesuai dengan tujuan yang akan dicapai, dan efektif dalam menggali kemampuan peserta didik dalam pembelajaran. Hal ini sesuai dengan pendapat Titin \& Dara (2016) bahwa bahan ajar hendaklah sesuai dengan tujuan pembelajaran, sesuai dengan kebutuhan peserta didik, penyajiannya harus faktual, menggambarkan latar belakang dan suasana yang dihayati oleh peserta didik, mudah dan ekonomis penggunaannya, serta lingkungan bahan ajar yang digunakan harus tepat sesuai dengan media yang digunakan.

Aspek manfaat/kegunaan materi ajar yang dikembangkan memproleh kategori sangat valid, sehingga dapat dikatakan bahwa materi ajar dapat digunakan sebagai pedoman bagi guru dalam pembelajaran dan juga dapat digunakan sebagai pedoman bagi peserta didik dalam belajar mandiri. Maka dari itu, materi ajar yang dikembangkan dapat dikatakan telah baik dan 
dapat digunakan sebagai panduan dalam proses pembelajaran yang berorientasi pada pelatihan keterampilan pemecahan masalah bermuatan pembelajaran otentik. Hal ini sejalan dengan Trevathan \& Myers (2013) bahwa bahan ajar yang dirancang untuk melatihkan keterampilan pemecahan masalah dapat sekaligus melatihkan kemampuan berpikir tingkat tinggi pada peserta didik melalui kegiatan mengeksplorasi permasalahan sekitar sehingga diperoleh pemahaman konseptual yang lebih baik.

\section{KESIMPULAN}

Diperoleh simpulan bahwa bahan ajar gerak melingkar berbasis authentic learing untuk melatihkan keterampilan pemecahan masalah peserta didik dinyatakan valid. Bahan ajar ini dapat digunakan sebagai sumber belajar untuk peserta didik tingkat sekolah menengah atas.

\section{DAFTAR PUSTAKA}

Akbar, S. (2016). Instrumen perangkat pembelajaran. Bandung: PT Remaja Rosdakarya Offset.

Amrita, P. D., Jamal, M. A., \& Misbah, M. (2016). Meningkatkan kemampuan pemecahan masalah siswa melalui model pengajaran langsung pada pembelajaran fisika di kelas $\mathrm{x}$ ms 4 SMA Negeri 2 Banjarmasin. Berkala Ilmiah Pendidikan Fisika, 4(3), 248-261.

Astra, I. M., \& Jannah, M. (2012). Pengaruh Model Pembelajaran Problem Posing Tipe PreSolution Posing Terhadap Hasil Belajar Fisika dan Karakter Siswa SMA. Jurnal Pendidikan Fisika Indonesia, 8(2).

Azizah, R., Yuliati, L., \& Latifah, E. (2015). Kesulitan Pemecahan Masalah Fisika Pada Siswa SMA. Jurnal Penelitian Fisika Dan Aplikasinya (JPFA), 5(2), 44-50.

Damayanti, D. S. (2013). Pengembangan Lembar Kerja Siswa (LKS) Dengan Pendekatan Inkuiri Terbimbing Untuk Mengoptimalkan Kemampuan Berpikir Kritis Peserta Didik Pada Materi Listrik Dinamis SMA Negeri 3
Purworejo Kelas X Tahun Pelaaran 2012/2013. Jurnal Berkala Pendidikan Fisika, 3(1), 58-62.

Fayakun, M., \& Joko, P. (2015). Efektivitas Pembelajaran Fisika Menggunakan Model Kontekstual (CTL) Dengan Metode Predict, Observe, Explain Terhadap Kemampuan Berpikir Tingkat Tinggi. Jurnal Pendidikan Fisika Indonesia, 11(1), 49-58.

Griyanika, L. (2014). Pengembangan Modul Pengayaan Berbasis Authentic Learning pada Materi Pokok Fluida Statis untuk Melatih Motivasi Belajar dan Kemampuan Berpikir Kritis Peserta Didik Kelas XI SMA. Universitas Negeri Yogyakarta.

Habibi, M., Zainuddin, Z., \& Misbah, M. (2017). Pengembangan Perangkat Pembelajaran IPA Fisika Berorientasi Kemampuan Pemecahan Masalah Menggunakan Model Pengajaran Langsung Pada Pokok Bahasan Tekanan di SMP Negeri 11 Banjarmasin. Berkala Ilmiah Pendidikan Fisika, 5(1): 1-17.

Hartini, S., Firdausi, S., Misbah, M., \& Sulaeman, N. F. (2018). The development of physics teaching materials based on local wisdom to train saraba kawa characters. Jurnal Pendidikan IPA Indonesia, 7(2), 130-137.

Hartini, S., Isnanda, M. F., Wati, M., Misbah, M., An'Nur, S., \& Mahtari, S. (2018). Developing a physics module based on the local wisdom of Hulu Sungai Tengah regency to train the murakata character. Journal of Physics: Conference Series, 1088, 1-6.

Hasani, N. L., Hartini, S., \& Annur, S. (2019). Meningkatkan Keterampilan Proses Sains dan Karakter Kayuh Baimbai melalui Modul Fisika Bermuatan Kearifan Lokal. Jurnal Ilmiah Pendidikan Fisika, 3(2), 65-76.

Heller, P., Keith, R., \& Anderson, S. (1992). Teaching Problem Solving through Cooperative Grouping. Part 1: Group versus Individual Problem Solving. American Journal of Physics, 60(7), 627-636.

Iriani, R., Herlina, A., Irhasyuarna, Y., \& Sanjaya, R. E. (2019). Modul pembelajaran problembased learning berbasis lahan basah untuk mempersiapkan calon pendidik 
berwawasan lingkungan lahan basah. Jurnal Inovasi Pendidikan IPA, 5(1), 54-68.

Khair, A. (2003). Sinoman Hadrah Seni Islam yang Perlu Diperhatikan. Himmah, 4(10), 45-54.

Lombardi, M. M. (2007). Authentic Learning for the 21st Century: An Overview. ELI Paper 1.

Markawi, N. (2015). Pengaruh Keterampilan Proses Sains, Penalaran, dan Pemecahan Masalah terhadap Hasil Belajar Fisika. Formatif: Jurnal Ilmiah Pendidikan MIPA, $3(1)$.

Matondang, Z. (2009). Validitas dan Reliabilitas Suatu Instrumen Penelitian. Jurnal Tabularasa PPS Enimed, 6(1), 87-97.

Maulida, R., \& Simanjuntak, M. P. (2015). Pengembangan Bahan Ajar Fisika SMA Berbasis Investigasi pada Materi Fluida Dinamis untuk Meningkatkan Hasil Belajar Siswa. Jurnal Pendidikan Fisika, 4(1), 71-76.

Misbah, M., \& Fuad, Z. (2019). Pengintegrasian Kearifan Lokal Kalimantan Selatan dalam Pembelajaran Fisika. In Prosiding Seminar Nasional Pendidikan Fisika "Motogpe."

Misbah, M., Hirani, M., Annur, S., Sulaeman, N. F., \& Ibrahim, M. A. (2020). The development and validation of a local wisdom-integrated physics module to grow the students' character of sanggup bagawi gasan masyarakat. Jurnal Ilmu Pendidikan Fisika, 5(1), 1-7.

Novikasari, I. (2009). Pengembangan Kemampuan Berpikir Kritis Siswa Melalui Pembelajaran Matematika Open-Ended di Sekolah Dasar. INSANIA, 14(2), 346-364.

Nurhadiyanto, N. (2015). Pengaruh Manajemen Sumber Belajar Terhadap Prestasi Belajar dengan Kemampuan Berpikir Kritis dan Kemampuan Bahasa Inggris sebagai Variabel Moderasi di Amik Cipta Darma Surakarta. Among Makarti, 8(15), 54-67.

Prasetiyo, N. A., \& Perwiraningtyas, P. (2017). Pengembangan Buku Ajar Berbasis Lingkungan Hidup pada Mata Kuliah Biologi di Universitas Tribhuwana Tunggadewi. Jurnal Pendidikan Biologi Indonesia, 3(1), 19-27.
Prastowo, A. (2014). Panduan kreatif membuat bahan ajar inovatif. Yogyakarta: Diva Press.

Polya, G. (1973). How to Solve It: A New Aspect of Mathematical Method. New Jersey: Princeton University Press.

Rahmah, L. A. (2018). Pengembangan Modul Fisika Materi Getaran Harmonis Bermuatan Authentic Learning untuk Melatih Kemampuan Pemecahan Masalah. Skripsi. Universitas Lambung Mangkurat, Banjarmasin: Tidak Dipublikasikan.

Santyadiputra, G. D., \& Pradnyana, I. M. A. (2017). Validasi Bahan Ajar Berbasis Model ProjectBased Learning pada Mata Kuliah Sistem Informasi. Seminar Nasional Riset Inovatif, 352-359.

Sari, R. T. (2017). Uji Validitas Modul Pembelajaran Biologi pada Materi Sistem Reproduksi Manusia melalui Pendekatan Konstruktivisme untuk Kelas IX SMP. Scientiae Educatia: Jurnal Pendidikan Sains, 6(1), 22-26.

Satriawan, K., \& Rosmiati, R. (2016). Pengembangan Bahan Ajar Fisika Berbasis Kontekstual dengan Mengintegrasikan Kearifan Lokal untuk Meningkatkan Pemahaman Konsep Fisika pada Mahasiswa. Jurnal Penelitian Pendidikan Sains, 6(1), 1212-1217.

Selamet, K., Sadia, I. W., \& Suma, K. (2013). Pengaruh Model Pembelajaran Kontekstual REACT terhadap Pemahaman Konsep Fisika dan Keterampilan Proses Sains Siswa Kelas VIII SMP. Jurnal Pendidikan Dan Pembelajaran IPA Indonesia, 3(1).

Sulistiani, D. (2018). Penerapan Metode Outentic Learning dapat Meningkatkan Pembelajaran Ilmu Pengetahuan Alam. JPG: Jurnal Penelitian Guru FKIP Universitas Subang, 1(2), 23-32.

Sutiniasih, N. K. (2018). Pengembangan Modul Materi Usaha dan Energi Bermuatan Authentic Learning untuk Melatihkan Kemampuan Pemecahan Masalah. Skripsi. Universitas Lambung Mangkurat, Banjarmasin: Tidak dipublikasikan.

Titin, T., \& Dara, E. N. (2016). Penyusunan 
Perangkat Pembelajaran pada Materi Ruang Lingkup Biologi Kelas X SMA. Jurnal Pendidikan Matematika Dan IPA, 7(1), 4556.

Trevathan, J., \& Myers, T. (2013). Towards Online Delivery of Process-Oriented Guided Inquiry Learning Techniques in Information Technology Courses. Journal of Learning Design, 6(2).

Triuitami, R. R., \& Ruwanto, B. (2017). Pengembangan Modul Pengayaan Berbasis Authentic Learning Pada Materi Pokok Fluida Dinamis Untuk Meningkatkan Motivasi Belajar Dan Pemahaman Konsep Peserta Didik Kelas XI SMA Negeri 1 Jatisrono. Journal Pendidikan Fisika, 4(5), 368-378.

Widoyoko, S. E. P. (2017). Penilaian Hasil Pembelajaran di Sekolah. Yogyakarta: Pustaka Pelajar.

Yuberti, S. L., Anugrah, A., Saregar, A., Misbah,M., \& Jermsittiparsert, K. (2019). Approaching Problem-Solving Skills of Momentum and Impulse Phenomena Using Context and Problem-Based Learning. European Journal of Educational Research 8(4), 1217-1227.

Yunita, A., Saadi, P., \& Kusasi, M. (2018). Pemanfaatan sumber belajar dari lingkungan lahan basah melalui pendekatan ctl terhadap hasil belajar pada pembelajaran larutan asam basa. Prosiding Seminar Nasional Pendidikan Kimia Universitas Lambung Mangkurat, 20-28. 